\title{
Viscosity of andesitic lava and its implications for possible drain-back processes in the 2011 eruption of the Shinmoedake volcano, Japan
}

\author{
Hiroaki Sato $^{1,2}$, Keiko Suzuki-Kamata ${ }^{2}$, Eiichi Sato $^{3}$, Kyohei Sano $^{4 *}$, Keiji Wada $^{4}$, and Ryusuke Imura ${ }^{5}$ \\ ${ }^{1}$ Center for Integrated Research and Education of Natural Hazards, Shizuoka University, 836 Ohya, Suruga-ku, Shizuoka 422-8529, Japan \\ ${ }^{2}$ Department of Earth and Planetary Sciences, Graduate School of Science, Kobe University, 1-1 Rokkodai, Nada-ku, Kobe 657-8501, Japan \\ ${ }^{3}$ Institute for Promotion of Higher Education, Kobe University, 1-2-1 Tsurukabuto, Nada-ku, Kobe 657-8501, Japan \\ ${ }^{4}$ Hokkaido University of Education at Asahikawa, Hokumon-cho 9, Asahikawa, Hokkaido 070-8621, Japan \\ ${ }^{5}$ Department of Earth Sciences, Kagoshima University, Korimoto, Kagoshima 990-0085, Japan
}

(Received September 29, 2012; Revised May 6, 2013; Accepted May 29, 2013; Online published July 8, 2013)

\begin{abstract}
The $850 \mathrm{~m}$ diameter crater of the Shinmoedake volcano was filled by andesitic lava after three subplinian eruptions on 26-27 January 2011. We analyzed blocks thrown from the lava-filled crater by subsequent Vulcanian explosions to estimate the lava's viscosity and evaluate the possibility of drain-back processes in the crater. Petrographic work on the ejecta, including bulk and glass chemistry, phenocryst and microlite modes, and the water content of the glass enabled us to estimate the bulk viscosity of the lava to be $10^{9.8(+1.5-1.2)} \mathrm{Pa}$. The conduit radius is constrained to 4.5 to $6 \mathrm{~m}$ by the eruption rate of preceding subplinian eruptions $\left(450-740 \mathrm{~m}^{3} / \mathrm{s}\right.$ dense rock equivalent). We estimate the simple drain-back rate of the lava to be $3 \times 10^{-2} \sim 2 \times 10^{-5} \mathrm{~m}^{3} / \mathrm{s}$. At this rate, less than 1 percent of the total amount of the effused lava could drain back within 100 days. Synthetic aperture radar (SAR) observations did not reveal evidence of drain-back after the eruption, possibly because the chamber was sustained, at least in part by repressurization and refilling as observed by global navigation satellite system (GNSS) measurements of the volcano. This study showed that degassing and crystallization of the andesitic magma during emplacement increased magma viscosity by more than five orders of magnitude, prohibiting drain-back of the lava that filled the crater after the emplacement.
\end{abstract}

Key words: Degassing-induced crystallization, viscosity, andesite, Kirishima volcano group, lava drain-back.

\section{Introduction}

Effused lava will sometimes return to the subsurface by flowing into an open vent or conduit in a process called drain-back. Drain-back is a common phenomenon for basaltic magmas. The Kilauea Iki lava lake and other pit craters experience drain-back of lavas containing 49-52 wt $\% \mathrm{SiO}_{2}$ (Swanson, 1972; Barker et al., 1998; Wallace and Anderson, 1998). At ridge crests, Fox et al. (2001) and Chadwick (2003) observed pillar structures, which suggest that drain-back of ocean floor basalt containing 48-50 wt \% $\mathrm{SiO}_{2}$ has occurred. Island arc tholeiite with 51-53 wt \% $\mathrm{SiO}_{2}$ also drained back during the 1986-1987 eruption of the Izu Oshima volcano, Japan (Ida et al., 1988; Watanabe et al., 1999). These examples are consistent with smallscale supercooling and viscosity increases of basaltic magmas through degassing and crystallization during extrusion. In contrast, dacitic and rhyolitic magmas have much lower liquidus temperatures when their water content is high than when they are dry (e.g., Johannes and Holtz, 1996), so

*Present address: Department of Earth and Planetary Sciences, Graduate School of Science, Kyushu University, 6-10-1 Hakozaki, Higashi-ku, Fukuoka 812-8581, Japan.

Copyright (c) The Society of Geomagnetism and Earth, Planetary and Space Sciences (SGEPSS); The Seismological Society of Japan; The Volcanological Society of Japan; The Geodetic Society of Japan; The Japanese Society for Planetary Sciences; TERRAPUB.

doi:10.5047/eps.2013.05.018 they experience significant undercooling by degassing during eruption. Such degassed magma may be very viscous due to crystallization in the matrix, thus prohibiting magma drain-back to the conduit and chambers. At Mt. Showashinzan, the extruded dacite dome lava $\left(69 \mathrm{wt} \% \mathrm{SiO}_{2}\right.$, Oba et al., 1983) had a high viscosity, around $10^{10} \mathrm{~Pa}$ s (Minakami et al., 1951), and no magma drain-back occurred. Dacite lava (62-64 wt\% $\mathrm{SiO}_{2}$ ) from the 1980-1986 eruption of Mt. St. Helens (Swanson and Holcomb, 1990) and dacite lava (64-66 wt\% $\mathrm{SiO}_{2}$ ) from the1991-1995 eruption of Mt. Unzen (Nakada et al., 1999) did not drain back. Urabe et al. (2006) suggested possible drain-back of andesitic lava (58 $\mathrm{wt} \% \mathrm{SiO}_{2}$, Miyake et al., 2005) in the crater of Mt. Asama during its 2004 eruptions. Urabe et al. (2006) estimated that about $20 \%$ of the extruded lava drained back.

During the 2011 eruption of Shinmoedake in the Kirishima volcano group in southern Japan, the crater, which is about 850 in diameter, was filled with andesitic lava up to 130 meters thick after three subplinian pumice eruptions. Extrusion of the lava was followed by intermittent Vulcanian explosions, which threw hot lava blocks up to $3 \mathrm{~km}$ from the crater rim. In the present study, we gathered samples of these blocks and pumice and analyzed their rock chemistry and thermometry to estimate the viscosity of the andesitic lava that filled the crater. We estimated the conduit radius based on the eruption rates of the preceding subplinian eruptions using Mastin's (2002) CONFLOW program. The viscosity of the lava and the con- 


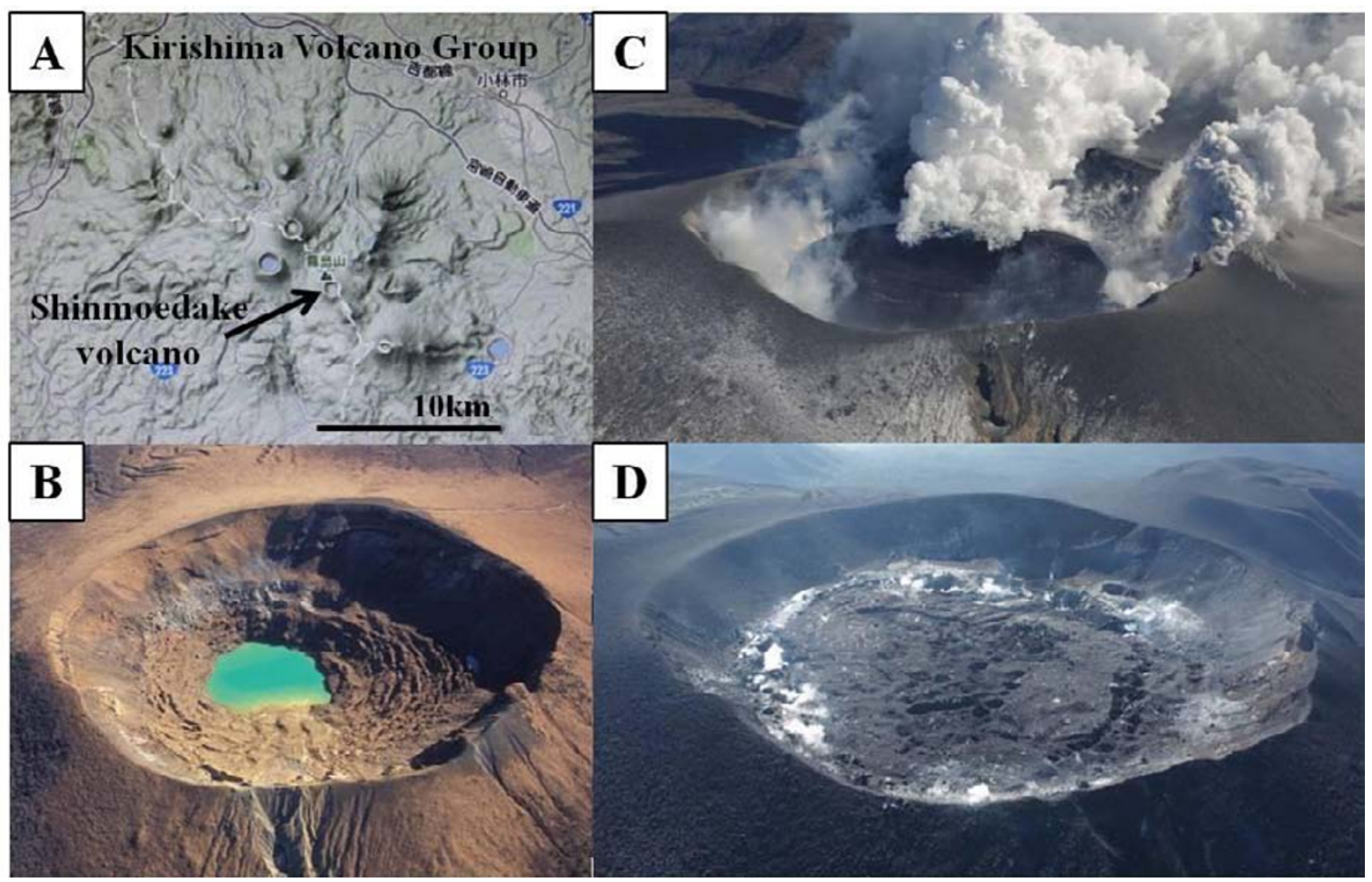

Fig. 1. Location of the Shinmoedake volcano of the Kirishima volcano group and photographs of the crater before, during and after the 2011 eruption of the Shinmoedake volcano. The crater of Shinmoedake in Figs. 1(B), 1(C), 1(D) is 850 meters across. A: Index map of the Kirishima volcano group showing the location of the Shinmoedake volcano, B: Photo taken 16 December 2003, C: Photo taken 31 January, 2011, D: Photo taken 7 September, 2012. All photos taken by Ryusuke Imura.

duit radius are used to evaluate the possible amounts of magma drain-back into the conduit due to gravity. This work may be the first trial of a technique to quantitatively evaluate lava viscosity and drain-back processes in active volcanoes. Phreatomagmatic explosions sometimes accompany lava drain-back (Ida et al., 1988), and assessment of andesitic lava may aid in mitigating the hazards of future eruptions of andesitic volcanoes.

\section{The 2011 Eruption of Shinmoedake Volcano in the Kirishima Volcano Group}

The Kirishima volcano group is situated in the south central part of Kyushu island in southern Japan. It consists of around 20 strato-cones, of which the Shinmoedake volcano is one of the youngest. It is located near the center of the volcano group (Fig. 1(A)). There are historic records of Shinmoedake eruptions, among which the 1716-1717 eruption was the largest (Imura, 1994). It produced subplinian fall deposits with some surge deposits to the east of the volcano. The total volume (dense rock equivalent, DRE) of the 1716-1717 eruption amounted to approximately $0.10 \mathrm{~km}^{3}$ (Imura and Kobayashi, 1991). Several phreatomagmatic eruptions were recorded in 1778, 1818 and 1914. For nearly one year before the 2011 eruption, the volcanic edifice gradually inflated as recorded by GPS baseline measurements by Nakao et al. (2011), and there were some small scale phreatic and phreatomagmatic eruptions.

The 2011 eruption of the Shinmoedake volcano began on 26 January with three subplinian explosions followed by extrusion of lava. The subplinian explosions occurred at 16:00 local time (+9:00 of UTC) on 26 January, and at 02:00 and 14:00 on 27 January. Each lasted for 1 to 2 hours, and an ash-laden cloud rose about $8000 \mathrm{~m}$ above sea level. Lava effusion was first detected on 29 January and slowly grew to its present size by 31 January. It formed a conforming flat circular form, about $600 \mathrm{~m}$ in diameter with a maximum thickness of $130 \mathrm{~m}$. The total eruption volumes of the explosive and effusive eruptions are $0.015 \mathrm{~km}^{3}$ and $0.015 \mathrm{~km}^{3}$, respectively, totaling about $0.030 \mathrm{~km}^{3}$ (DRE, Kozono et al., 2013). The eruption rates of the subplinian explosions are estimated to be from $450-741 \mathrm{~m}^{3} / \mathrm{s}$, and the lava effusion rates from $70-87 \mathrm{~m}^{3} / \mathrm{s}$ (DRE, Kozono et al., 2013). There were intermittent vulcanian explosions for three months after the lava was emplaced in the crater. Each vulcanian explosion lasted for up to a few minutes and the resulting ash-laden cloud rose up to about 3000 meters. Sometimes the explosions threw large, hot blocks a few meters across up to $3 \mathrm{~km}$ from the crater rim.

Figures 1(B), 1(C) and 1(D) show pre-, mid- and posteruption pictures of the Shinmoedake volcano crater, respectively. The pre-eruption figure shows a pond at the bottom of the crater surrounded by ring-fault structures of the crater's hanging wall. We investigated blocks from these ring-fault areas in 2005, and found that they represent welded spatters. Therefore, we suggest that before the 2011 eruption there was no lava filling the crater. On the other hand, Fig. 1(C) (mid-eruption) shows that the crater is filled by lava about 130 meters thick with surface wrinkle structures. Satellite synthetic aperture radar (SAR) interferometric measurements indicate that the volume of lava 
is about $1.5 \times 10^{7} \mathrm{~m}^{3}$, with the volume staying within the measurement uncertainty $\left(\sim 0.1 \times 10^{7} \mathrm{~m}^{3}\right)$ for more than 1 year (Ozawa, 2011). Thus, the lava filling the crater did not show evidence of drain-back. However, lava did drain back after an andesitic eruption of Mt. Asama in 2004 (Urabe et al., 2006), and caution was urged with regard to phreatomagmatic explosions that may accompany impending lava drain-back.

\section{Sample and Analytical Methods}

We obtained three kinds of eruption products from the Shinmoedake volcano: white pumice, which is rarely found in the deposits of subplinian eruptions; gray pumice, which dominates the ejecta of subplinian eruptions; and lava blocks thrown by Vulcanian explosions, derived from the lava-filled crater. The lava blocks were found about 2.6 kilometers NNW of Shinmoedake volcano on 1 February 2011. They were sampled and described by Prof. Shimizu and Dr. Matsushima of Kyushu University. Two samples were used for this study. Both have rough bread-crust surfaces and are 50-100 cm across. The blocks' impacts formed craters 6-10 meters across and 1-2 meters deep. Surrounding tree trunks were baked by the blocks' heat. Because the blocks were thrown by Vulcanian explosions early in the morning of 1 February 2011, just after the emplacement of the lava in the crater, they may represent part of that lava. We undertook the present study to estimate the viscosity of the emplaced lava and evaluate the possibility of drain-back of the lava that filled the crater.

We determined the abundance of phenocrysts by pointcounting thin, polished sections under a microscope in both reflected and transmitted light. Two thousand points were counted, including vesicles. Care was taken to confirm vesicles under reflected light. We determined the matrix crystal contents by analyzing backscatter electron images. The raw images were corrected using Adobe Photoshop, and analyzed using ImageJ to obtain the total area of specific phases such as voids, plagioclase, glass, oxides and pyroxene.

The samples' bulk rock composition was analyzed using an X-ray fluorescence spectrometer (RIGAKU 3270E) at the Graduate School of Human Studies, Kobe University and by the Australian Laboratory Service (ALS).

The chemical composition of the glass was determined at the Center for Instrumental Analyses at Kobe University using an electron probe microanalyzer (JEOL JXA8900) with $15 \mathrm{KV}$ acceleration voltage and electron current of approximately $12 \mathrm{nA}$. A broad beam of 10 microns across was used, and the counting times were mostly $20 \mathrm{~s}$ at the peak with $10 \mathrm{~s}$ of background counting on both sides of the peak wavelength. For $\mathrm{Na}$ analyses, the counting time was $4 \mathrm{~s}$ without a peak search but with $2 \mathrm{~s}$ of background counting to avoid Na loss during counting. The background corrected raw counts were processed using the ZAF program to obtain the oxide weight percents.

The $\mathrm{H}_{2} \mathrm{O}(+)$ contents of the bulk samples, representing percent of water extracted from the sample above $110^{\circ} \mathrm{C}$, were measured using a Karl-Fischer titration module (Hiranumasangyo Co. Ltd, AQ-2000ST, EV-5A) at the Hokkaido University of Education at Asahikawa following the method of Westrich (1987). 0.1-0.3 gram samples were weighed and heated at $110^{\circ} \mathrm{C}$ for 1 day. The samples were then heated in a furnace to $1000^{\circ} \mathrm{C}$, and the expelled $\mathrm{H}_{2} \mathrm{O}$, transferred by dry $\mathrm{N}_{2}$ gas, was measured using KarlFischer titration. Triplicate analyses were done for each sample, and the values were averaged to represent the sample's $\mathrm{H}_{2} \mathrm{O}(+)$ content. Reproducibility of the analyses was generally within $0.02 \mathrm{wt} \%$, better than the variability among samples, except for the analyses of the white pumice. Because the gray pumice and lava block samples were charged with microlites in the matrix, we did not use micro-FTIR.

\section{Analytical Results}

The phenocrysts in the samples consisted of olivine, plagioclase, augite, orthopyroxene, magnetite, and ilmenite, and the groundmass comprises augite, orthopyroxene, plagioclase, magnetite and glass. Figure 3 shows representative back-scattered electron images of the three types of 2011 ejecta. The total phenocryst fraction of white pumice is $0.458 \pm 0.042$, whereas the microlite fraction in the groundmass is 0.0016 (Fig. 3(A)). For gray pumice, phenocryst fraction is $0.323 \pm 0.089$, and microlite fraction in the groundmass is $0.30 \pm 0.02$ (Fig. 3(B)). For the Vulcanian blocks, phenocryst fraction is $0.295 \pm 0.029$, and microlite fraction in the groundmass is $0.427 \pm 0.027$ (Fig. 3(C)). The bulk crystallinity (in fraction) is calculated from these data; i.e. [bulk crystallinity] $=$ [phenocryst fraction $]+$ [groundmass fraction $] \times[$ microlite fraction in the groundmass]. The bulk crystallinities of white pumice, gray pumice and Vulcanian block are $0.458 \pm 0.042,0.526 \pm$ 0.094 and $0.596 \pm 0.037$, respectively.

The bulk rock and glass compositions are shown in Table 1 and Fig. 2. The $\mathrm{SiO}_{2}$ content of the bulk rock was 56.5-58.5 wt \% for the gray pumice and Vulcanian blocks, and $61-62 \mathrm{wt} \%$ for the white pumice. The $\mathrm{SiO}_{2}$ contents of the glass in the white pumice ranged from 74 to $76 \mathrm{wt} \%$, predominantly at about $75 \mathrm{wt} \%$. The $\mathrm{SiO}_{2}$ contents of the glass in the gray pumice ranged from $65 \mathrm{wt} \%$ to $71 \mathrm{wt} \%$, mainly falling at around $67 \mathrm{wt} \%$. The glass composition in the matrix of the Vulcanian blocks ranged from $71 \mathrm{wt} \%$ to $73 \mathrm{wt} \% \mathrm{SiO}_{2}$, mostly around $72 \mathrm{wt} \%$ (Fig. 2). Most of the oxides show monotonous variation against the $\mathrm{SiO}_{2}$ concentration. The more evolved composition of the matrix glass in the Vulcanian blocks, compared with that in the gray pumice is due to enhanced microlite crystallization.

The bulk rock water contents of three white pumice grains varied widely $(0.16,1.2$ and $2.1 \mathrm{wt} \%)$. This is somewhat odd when we see the similar modal contents of their phenocrysts and their almost microlite-free matrices. The bulk water content of the gray pumice grains and the lava block samples were consistent at $0.139 \pm 0.21 \mathrm{wt} \%$ and $0.114 \pm 0.04 \mathrm{wt} \%$, respectively. We calculated the water content of the glass from the bulk water content and the modal content of the crystals, assuming that the nominally anhydrous minerals were water-free. The water content of the gray pumice was $0.293 \pm 0.073 \mathrm{wt} \%$, and that of the lava blocks was $0.282 \pm 0.028$.

We also carried out thermometry on the samples to analyze contiguous pyroxenes pairs utilizing the QUILF software package (Anderson et al., 1993). Although we also analyzed contiguous magnetite-ilmenite pairs, most of the 
Table 1.

\begin{tabular}{|c|c|c|c|c|}
\hline & unit & White pumice & Gray pumice & Lava Block \\
\hline Bulk rock [n]* & & {$[2]$} & {$[11]$} & {$[12]$} \\
\hline $\mathrm{SiO}_{2}$ & wt $\%$ & $62.03(03)$ & $58.25(19)$ & $57.61(21)$ \\
\hline $\mathrm{TiO}_{2}$ & $\mathrm{wt} \%$ & $0.65((02)$ & $0.73(00)$ & $0.72(01)$ \\
\hline $\mathrm{Al}_{2} \mathrm{O}_{3}$ & $\mathrm{wt} \%$ & $16.26(28)$ & $17.23(23)$ & $17.39(16)$ \\
\hline $\mathrm{FeO}$ total & wt $\%$ & $6.83(12)$ & $7.34(13)$ & $7.64(11)$ \\
\hline $\mathrm{MnO}$ & wt $\%$ & $0.12(00)$ & $0.13(00)$ & $0.14(01)$ \\
\hline $\mathrm{MgO}$ & $\mathrm{wt} \%$ & $2.72(18)$ & $3.92(12)$ & $4.20(09)$ \\
\hline $\mathrm{CaO}$ & wt $\%$ & $5.95(02)$ & $7.86(13)$ & $7.72(09)$ \\
\hline $\mathrm{Na}_{2} \mathrm{O}$ & $\mathrm{wt} \%$ & $2.99(05)$ & $2.80(02)$ & $2.85(05)$ \\
\hline $\mathrm{K}_{2} \mathrm{O}$ & $\mathrm{wt} \%$ & $2.35(00)$ & $1.63(04)$ & $1.60(02)$ \\
\hline $\mathrm{P}_{2} \mathrm{O}_{5}$ & wt $\%$ & $0.11(00)$ & $0.12(01)$ & $0.11(00)$ \\
\hline Total & $\mathrm{wt} \%$ & 100.00 & 100.00 & 100.00 \\
\hline $\begin{array}{l}\text { Bulk } \mathrm{H}_{2} \mathrm{O} \text { analyses [n] } \\
\mathrm{H}_{2} \mathrm{O}\end{array}$ & $\mathrm{wt} \%$ & $\begin{array}{c}{[3]} \\
0.164,0.51,2.16\end{array}$ & $\begin{array}{c}{[7]} \\
0.139(21) \\
\end{array}$ & $\begin{array}{c}{[2]} \\
0.114(4)\end{array}$ \\
\hline Phenocryst Mode [n] & & {$[3]$} & [7] & [7] \\
\hline Plagioclase & fraction & $0.383(62)$ & $0.249(80)$ & $0.225(21)$ \\
\hline Olivine & fraction & - & $0.014(7)$ & $0.023(7)$ \\
\hline Augite & fraction & $0.039(15)$ & $0.036(18)$ & $0.017(6)$ \\
\hline Orthopyroxene & fraction & $0.023(8)$ & $0.014(7)$ & $0.019(3)$ \\
\hline Magnetite & fraction & $0.012(1)$ & $0.007(3)$ & $0.011(6)$ \\
\hline Groundmass & fraction & $0.542(42)$ & $0.677(89)$ & $0.705(29)$ \\
\hline Total & fraction & 1.000 & 1.000 & 1.000 \\
\hline Groundmass glass [n] & & [89] & [192] & [44] \\
\hline $\mathrm{SiO}_{2}$ & $\mathrm{wt} \%$ & $75.30(48)$ & $67.27(77)$ & $72.05(29)$ \\
\hline $\mathrm{TiO}_{2}$ & wt $\%$ & $0.31(03)$ & $0.76(6)$ & $0.70(04)$ \\
\hline $\mathrm{Al}_{2} \mathrm{O}_{3}$ & wt $\%$ & $12.09(13)$ & $14.19(34)$ & $11.96(18)$ \\
\hline $\mathrm{FeO}$ total & $\mathrm{wt} \%$ & $1.40(07)$ & $5.33(41)$ & $3.94(11)$ \\
\hline $\mathrm{MnO}$ & wt $\%$ & $0.02(01)$ & $0.05(1)$ & $0.03(01)$ \\
\hline $\mathrm{MgO}$ & wt $\%$ & $0.23(02)$ & $1.31(24)$ & $0.49(04)$ \\
\hline $\mathrm{CaO}$ & $\mathrm{wt} \%$ & $1.20(04)$ & $4.09(29)$ & $2.04(11)$ \\
\hline $\mathrm{Na}_{2} \mathrm{O}$ & wt $\%$ & $3.32(14)$ & $3.56(19)$ & $3.7(15)$ \\
\hline $\mathrm{K}_{2} \mathrm{O}$ & wt $\%$ & $4.62(07)$ & $2.93(14)$ & $4.03(06)$ \\
\hline Total & $\mathrm{wt} \%$ & $98.73(76)$ & $99.49(41)$ & $98.94(37)$ \\
\hline Groundmass [n] & & [3] & [2] & [3] \\
\hline microlite content & fraction & $0.0016(7)$ & $0.30(2)$ & $0.427(27)$ \\
\hline Bulk crystallinity & fraction & $0.458(42)$ & $0.526(94)$ & $0.596(37)$ \\
\hline Glass $\mathrm{H}_{2} \mathrm{O}$ content\# & $\mathrm{wt} \%$ & $0.303(33)$ & $0.293(73)$ & $0.282(28)$ \\
\hline \multirow[t]{2}{*}{ Temperature [n] } & & [6] & [3] & [6] \\
\hline & ${ }^{\circ} \mathrm{C}$ & 913(19) & $925(3)$ & $928(11)$ \\
\hline Viscosity (glass) $\$$ & $\log \mathrm{Pa} \mathrm{s}$ & 4.4-8.2 & $6.64(+22-20)$ & $7.11(+21-20)$ \\
\hline Viscosity (bulk) $\$ \$$ & $\log \mathrm{Pa} \mathrm{s}$ & $5.29-9.79$ & $8.44(+1.76-1.05)$ & $9.81(+1.47-1.19)$ \\
\hline
\end{tabular}

* number of analyses averaged

** number in parenthesis denote standard deviation in decimal unit

\# Glass $\mathrm{H}_{2} \mathrm{O}$ contents were calculated from the bulk $\mathrm{H}_{2} \mathrm{O}$ content and bulk crystallinity

$\$$ Viscosity of glass is calculated after Giordano et al.(2008) with errors taking into consideration of the errors of Glass $\mathrm{H}_{2} \mathrm{O}$ content and temperature

$\$$ V Viscosity of bulk lava is calculated by modified Einstein-Roscoe equation as described in the text

data indicated the rhombohedral phase to be in a disordered condition where the temperature estimation had large standard errors (Ghiorso and Evans, 2008), so we did not use that data. The analytical positioning of the pyroxene pairs was within 10 microns from the contact of the contiguous orthopyroxene and augite. The QUILF program gives standard temperature errors using four independent reactions, and we used the data if the standard temperature error was within $20^{\circ} \mathrm{C}$. The estimated temperature of the white pumice was $913 \pm 19^{\circ} \mathrm{C}$, that of gray pumice was $925 \pm 3^{\circ} \mathrm{C}$, and that of the lava blocks was $928 \pm 11^{\circ} \mathrm{C}$. These values slightly differ from the results of Suzuki et al. (2013). Suzuki et al. (2013) utilized the method of Putirka (2008) for pyroxene thermometry, and obtained $901 \pm 11^{\circ} \mathrm{C}$ for white pumice, $922 \pm 11^{\circ} \mathrm{C}$ for gray pumice, and $896 \pm 11^{\circ} \mathrm{C}$ for lava blocks. Suzuki et al. (2013) also obtained twooxide temperature and oxygen fugacity of $861-874^{\circ} \mathrm{C}$ and $\mathrm{NNO}+1.5$ for white pumice, $925-871^{\circ} \mathrm{C}$ and $\mathrm{NNO}+1.5$ for gray pumice and $886-864^{\circ} \mathrm{C}$ and $\mathrm{NNO}+1.5$ for lava block. The temperature obtained by pyroxene pairs of Suzuki et al. (2013) is slightly lower compared with our result. We used our thermometric data in the following discussion.

\section{Discussion}

\subsection{Viscosity of the extruded lava}

We determined the bulk viscosity of the extruded magma in the crater of Shinmoedake volcano from its glass composition, glass water contents, crystal contents and tempera- 

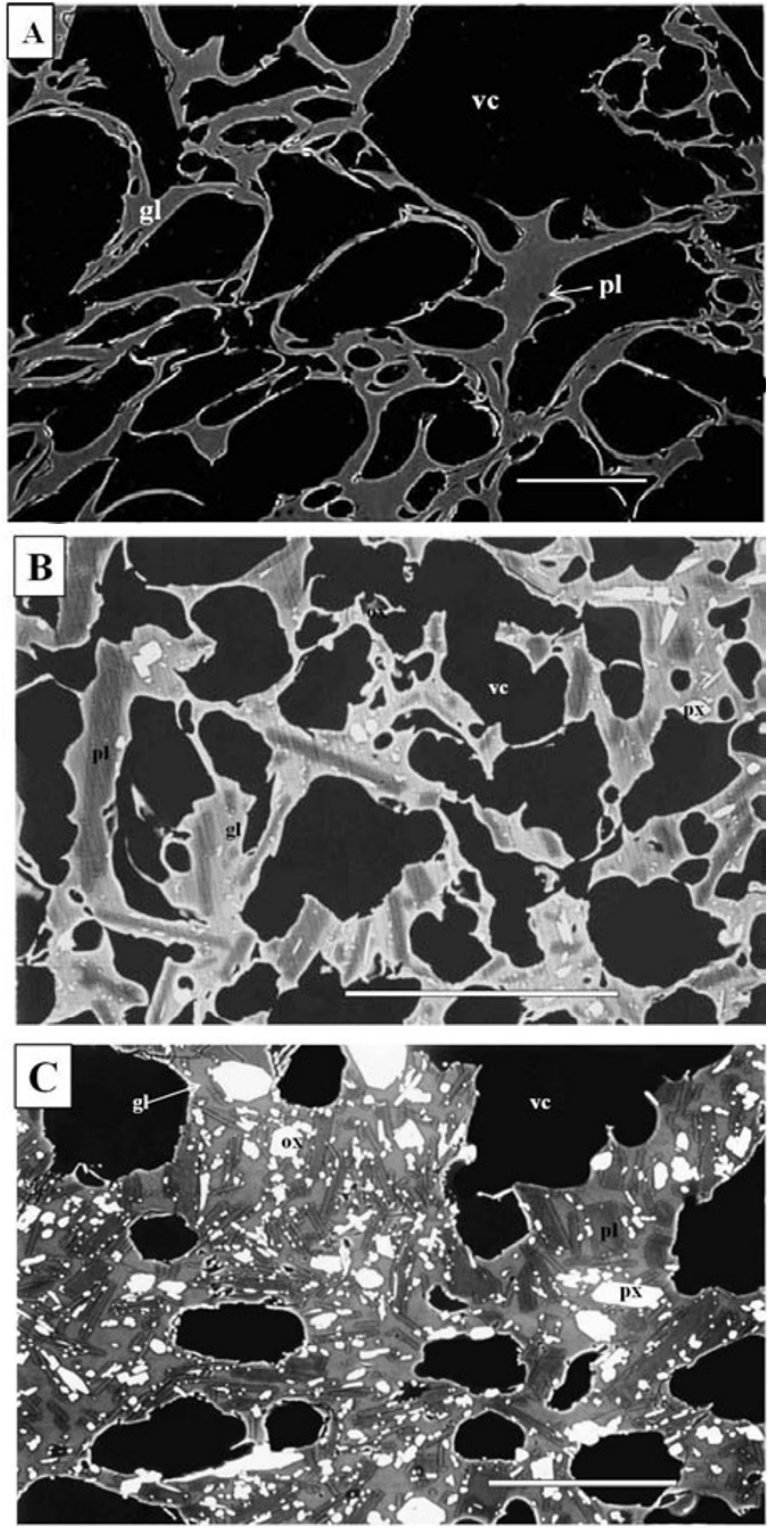

Fig. 2. Back-scattered electron images of the matrix of the erupted materials. A: White pumice, B: Gray pumice, C: Blocks ejected from the lava that filled the crater in 1 February 2011. Dark rectangles are plagioclase (labeled as 'pl'), bright crystals are either pyroxenes (px) or iron-titanium oxides (ox), gray areas represents matrix glass (gl), black areas are the vesicles (vs). Scale bars represent 100 micrometers.

ture. The $\mathrm{SiO}_{2}$ contents of the matrix glass of the Vulcanian blocks vary, so we used the average $\left(72 \mathrm{wt} \% \mathrm{SiO}_{2}\right)$ in our calculations (Table 1). We estimated the water content of the glass to be $0.28 \mathrm{wt} \%$. The temperature of the blocks, determined using contiguous pyroxene pairs, is $928^{\circ} \mathrm{C}$. The viscosity of the groundmass melt in the blocks was calculated to be $10^{6.9 \pm 0.2} \mathrm{~Pa}$ s using the equation of Giordano et al. (2008). The error in the glass viscosity was obtained by using the parameters that would give maximum and minimum viscosity values. The effect of crystals on the bulk viscosity has been shown to be variable (e.g., Costa et al., 2009), and many studies use forms of the Einstein-Roscoe or Krieger-Dougherty equations such that

$$
\eta_{r}=\frac{\eta_{b}}{\eta_{m}}=\left(1-\frac{\varphi}{\varphi_{m}}\right)^{-\varphi_{m} \varepsilon}
$$

where $\varphi_{m}$ denotes the maximum packing fraction of the solid and $\varepsilon$ denotes the effect of crystal interaction (Krieger and Dougherty, 1959). Marsh (1981) suggested that $\varphi_{m}$ should be 0.60 from petrographic evidence that there is an upper limit to the phenocryst content of lavas. Mueller et al. (2011) experimented on the effect of crystal shape on relative viscosity and suggested that $\varphi_{m}$ may be less than 0.65 , and $\varphi_{m} \varepsilon$ should be 2 . Mueller did not take the size dispersion of the crystals into account, and it may increase $\varphi_{m}$ (Ishibashi and Sato, 2007). We calculated the bulk viscosity from the glass viscosity and the K-D equation using $\varphi_{m}=0.65$ and $\varphi_{m} \varepsilon=2.5$. The error range is obtained by calculating the maximum and minimum relative viscosities using $\varphi_{m}=0.65$ and $\varphi_{m} \varepsilon=2-2.5$. The bulk viscosity for the lava block is calculated to be $10^{9.8(+1.5-1.2)} \mathrm{Pa}$ s for the block lava of the 2011 Shinmoedake volcano (Table 1).

We also estimated the viscosity of the andesitic magma in the chamber. From the bulk rock chemical composition and mode and average mineral chemistry of the phenocrysts, we calculated the bulk groundmass composition as $\mathrm{SiO}_{2}=64.8, \mathrm{TiO}_{2}=0.8, \mathrm{Al}_{2} \mathrm{O}_{3}=14.3, \mathrm{FeO}=6.7$, $\mathrm{MnO}=0.2, \mathrm{MgO}=2.5, \mathrm{CaO}=5.0, \mathrm{Na}_{2} \mathrm{O}=3.3$, $\mathrm{K}_{2} \mathrm{O}=2.5, \mathrm{P}_{2} \mathrm{O}_{5}=0.1 \mathrm{wt} \%$. The water content of the magma in the chamber is estimated to be 4-5 wt\% from the melt inclusion data of Suzuki et al. (2013). Assuming magmatic temperatures of $925^{\circ} \mathrm{C}$, the viscosity of the melt is calculated to be $10^{3.3-3.6} \mathrm{~Pa}$ s. Applying the KriegerDougherty equation with $\varphi_{m}$ of 0.65 and $\varphi_{m} \varepsilon$ of 2.5 , the bulk viscosity of the andesitic magma in the chamber is $10^{3.8-4.1} \mathrm{~Pa}$ s. As noted in the above paragraph, bulk viscosity of the andesite lava after emplacement is estimated to be $10^{9.6} \mathrm{~Pa}$ s. Therefore, the bulk viscosity of the andesitic magma increased by more than five orders of magnitude through degassing and crystallization during the extrusion of the lava.

\subsection{Estimate of the conduit radius from the mass erup- tion rate of the subplinian eruption}

We have few direct measures of the radius of the conduit of the Shinmoedake volcano. Apparently, the downsagging U-shaped geomorphology of the crater before the 2011 eruption (diameter: 850 meters) suggests a much smaller conduit diameter than the total crater diameter. The eruption rate of the subplinian phase of the 2011 eruption was $450-741 \mathrm{~m}^{3} / \mathrm{s}$ (DRE/s; Kozono et al., 2013). Assuming the rising speed of the ejecta to be $50-100 \mathrm{~m} / \mathrm{s}$, the crosssectional area of the conduit was provisionally calculated as $5-15 \mathrm{~m}^{2}$. This should be modified by multiplying the inverse of the density of the bulk pyroclastics (including the magma and gas of the gaseous flow in the conduit). It may be difficult to estimate the bulk density of the pyroclasts at the mouth of the vent. We modeled the subplinian phase of the eruption using CONFLOW (Mastin, 2002) to attempt to determine the density of the pyroclasts, taking the limitations of exit conditions of the pyroclastics at the vent into consideration. Either the pressure of the pyroclastics are atmospheric or the exit velocity is equal to the sound velocity of the pyroclastics (Jaupart and Tait, 1991). Temperature of magma in the conduit may decrease by adiabatic decompression, which may be buffered by heat of crystallization (Blundy et al., 2006). The amount of microlite crystalliza- 

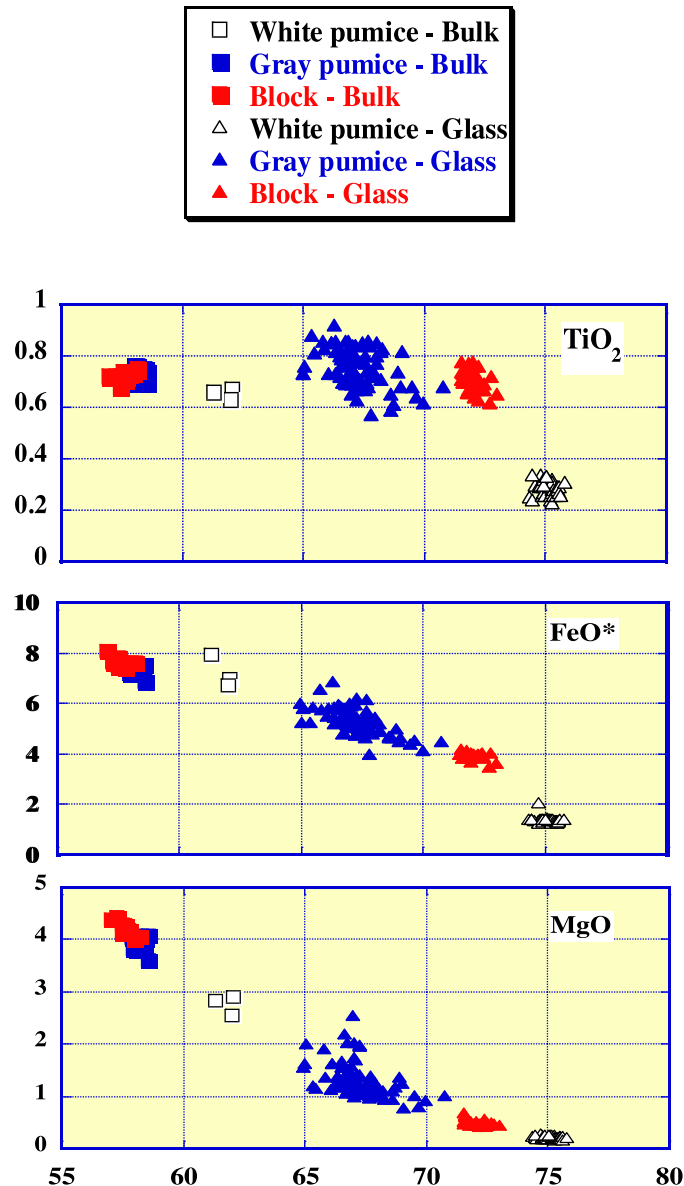
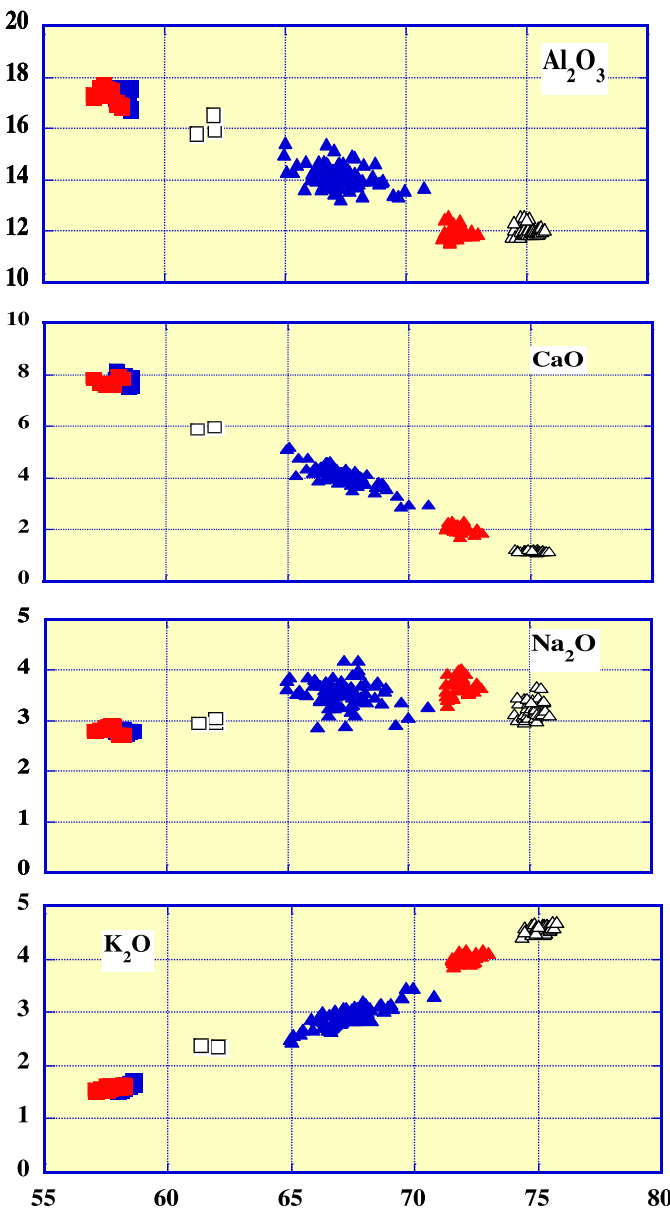

Fig. 3. Bulk rock and glass chemical compositions of white pumice, gray pumice and blocks from the lava that filled the crater. Bulk rock chemical composition is obtained by X-ray fluorescence analyses on bulk rock powder, whereas glass composition is obtained by electron-probe microanalyses.

tion in gray pumice is $20 \mathrm{vol} \%$ of the bulk rock, suggesting increase of temperature by $100^{\circ} \mathrm{C}$ if we assume $1 \mathrm{~J} / \mathrm{g}$ heat capacity and heat of fusion of $500 \mathrm{~J} / \mathrm{g}$ (e.g., Fukuyama, 1985). This temperature increase is slightly smaller compared with amount of temperature decrease in adiabatic decompression modeling of Mastin and Ghiorso (2001), where heat of crystallization is not taken into account. We calculated both the constant and adiabatic temperature variation of the conduit flow of Mastin and Ghiorso (2001), although both result in very similar estimated conduit radii (Fig. 4). Putting the magmatic temperature, water contents (4-5 wt\%), magma composition (above groundmass composition: $64.8 \mathrm{wt} \% \mathrm{SiO}_{2}$ ) and the phenocryst content into the program, we believe that the eruption rate is primarily dependent on the conduit diameter. It is not very dependent on the temperature and water contents of the magmas. Figure 4 illustrates the eruption rate versus conduit diameter relationship. Applying the eruption rate in the range from $450-741 \mathrm{~m}^{3} / \mathrm{s}$ results in a conduit radius estimate of $4.5-6$ meters (Fig. 4). The density of the pyroclasts at the vent was about $400-500 \mathrm{~kg} / \mathrm{m}^{3}$.

\subsection{Estimation of the drain-back rate of the andesitic lava filling the crater}

Drain-back of effused lava into its conduit may occur either by the collapse of the inflated magma's vesicles during the eruption or by lateral diking of the magma, both of which cause the formation of a void space in the conduit or magma chamber. In the 2011 eruption of the Shinmoedake volcano, the initial water contents of the magma ranged from 4-5 wt\% according to the water analyses of melt inclusions in the phenocrysts (Suzuki et al., 2013). The source of the inflation of the shallow magma chamber is situated about $5 \mathrm{~km}$ northwest of Shinmoedake at a depth of $9.8 \mathrm{~km}$ below sea level (Nakao et al., 2011; Kozono et al., 2013), corresponding to $285 \mathrm{MPa}$. The conduit length is estimated to be $10.8 \mathrm{~km}$ because the vent of Shinmoedake is at an altitude of $1 \mathrm{~km}$. The solubility of water at that pressure is 5-6 wt\% (Moore et al., 1998). Although we do not have exact observations of how magmas drain back after lava effusion, we assume that the vesiculated magma in the conduit may recede down the conduit due to its weight. In the case of the 2011 eruption of the Shinmoedake volcano, the effused lava in the crater is 130 meters thick. We take its weight into consideration as follows. Lava's drain-back rate due to its weight is expressed as follows (Kazahaya et al., 1994).

$$
Q_{\text {drainback }}=\frac{\pi\left(\rho_{1} g h+\rho_{2} g L\right) r^{4}}{8 \mu L}
$$

where $\rho_{1}, \rho_{2}, g, h, L, r$, and $\mu$ represent the density of extruded lava, the density of conduit lava, gravity's acceleration $\left(9.8 \mathrm{~m} / \mathrm{s}^{2}\right)$, the thickness of the extruded lava $(\mathrm{m})$, 


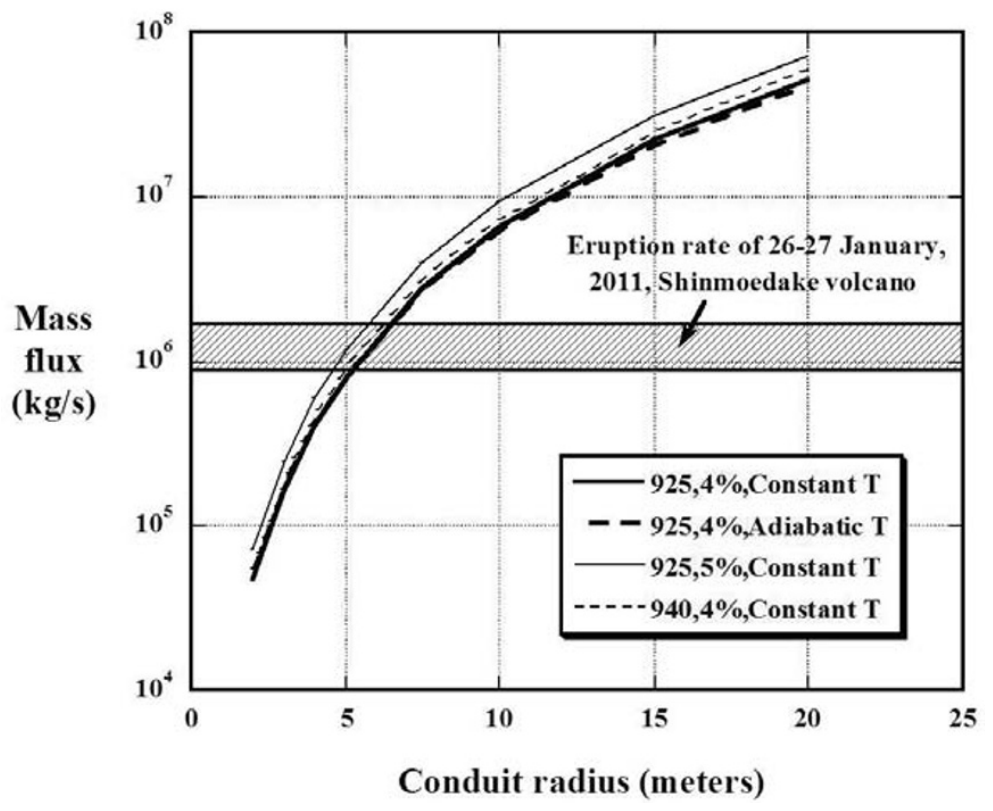

Fig. 4. Relationship between eruption rate and conduit radius for the initial Plinian phase of the 2011 eruption of the Shinmoedake volcano, following the CONFLOW model of Mastin (2002). Effect of temperature on the mass flux vs. conduit radius is shown for 925 and $940^{\circ} \mathrm{C}$, whereas effect of water content is shown for 4 and $5 \mathrm{wt} . \%$. The eruption rate for the sub-Plinian eruption is $9 \times 10^{5}-1.85 \times 10^{6} \mathrm{~kg} / \mathrm{s} \mathrm{calculated}$ by assuming density of magma of $2000-2500 \mathrm{~kg} / \mathrm{m}^{3}$ from the volumetric eruption rate of $450-741 \mathrm{~m}^{3} / \mathrm{s}$ (Kozono et al., 2013).

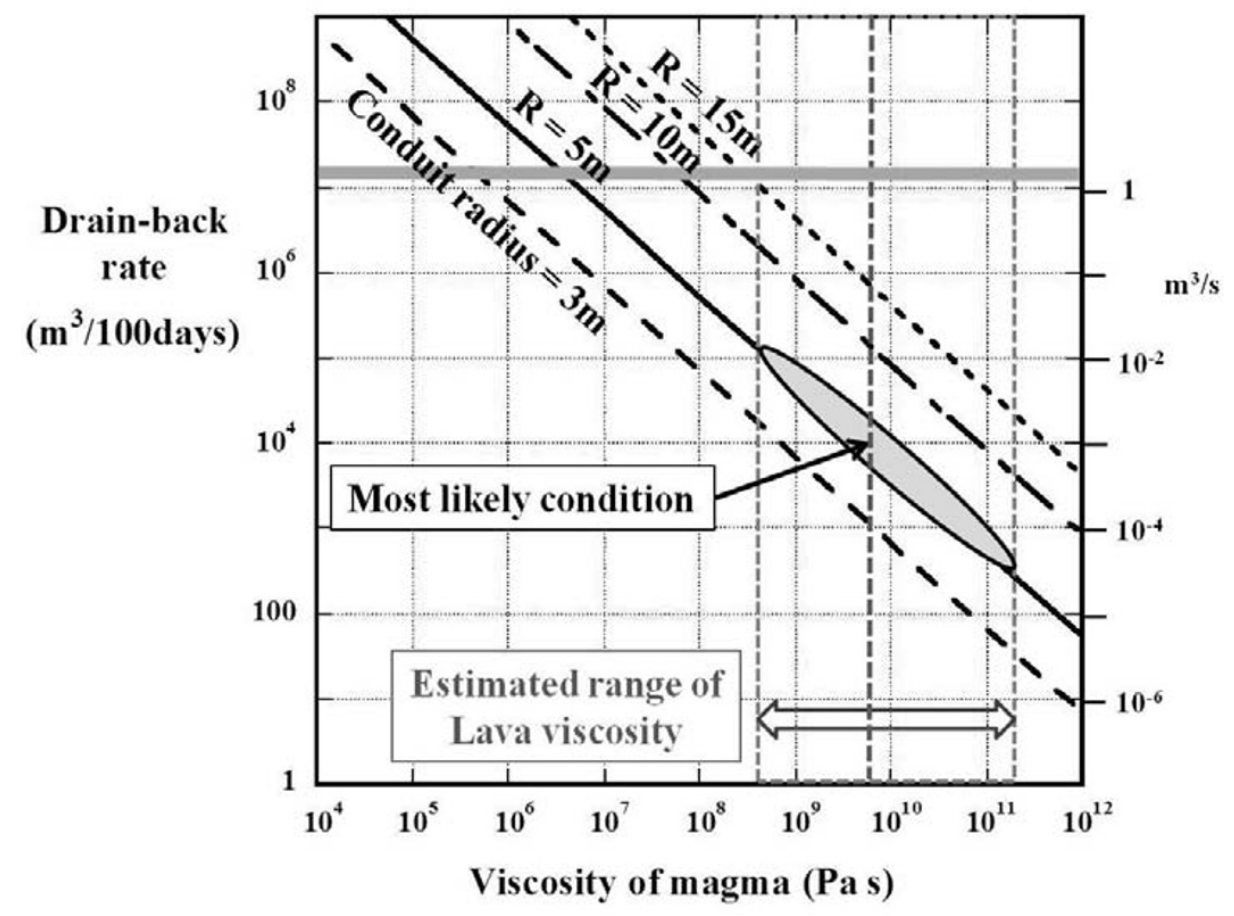

Fig. 5. Relationship between the drain-back rate (volume/100 days) and the viscosity (Pa s) of the lava. Both axes are logarithmic. Inclined lines show the drain-back rate and viscosity according to the equation in the text for different conduit radii $(r=3,5,10$, or 15 meters). The horizontal line at $(12.1-15.1) * 10^{6} \mathrm{~m}^{3}$ shows the total amount of effused lava (Kozono et al., 2013). The estimated value and error of lava viscosity are shown by vertical dotted lines. The inclined oval symbol shows the optimal estimate of the viscosity and conduit radius for the lava erupted from the Shinmoedake volcano in 2011, suggesting that less than 1 percent of the total lava may have drained back within 100 days of emplacement.

conduit length, conduit radius ( $\mathrm{m})$, and the bulk viscosity of the magma. Assuming that the conduit radius is $4.5-6 \mathrm{~m}$ and the densities of the lavas as $2500 \mathrm{~kg} / \mathrm{m}^{3}$, the drain-back rate is $2 \times 10^{2}-10^{5} \mathrm{~m}^{3} / 100$ days, corresponding to less than 1 vol. $\%$ of the total amount of lava effused into the crater of Shinmoedake volcano (Fig. 5). The equation above as- sumes that the extruded lava is drained mainly to the magma chamber, and may be rather conservative. Drain-back of effused lava may be caused by both shrinking of magma chamber and conduit after eruption and collapse of vesicles in the conduit and magma chamber. It is possible that magmas in the conduit and magma chamber have much lower 
viscosity due mainly to lower crystallinity and higher water content. In this case, shorter conduit length is expected for the drain-back process, although the result of the amount of drain-back of the extruded lava does not differ much from the calculation presented in Fig. 5.

\subsection{Implications of the analytical results}

Our petrographic analyses estimated a drain-back rate of $2 \times 10^{-2} \sim 3 \times 10^{-5} \mathrm{~m}^{3} / \mathrm{s}$ for the extruded lava in the Shinmoedake volcano crater. The rate's error is an order of magnitude, but the most likely value of about $10^{-3} \mathrm{~m}^{3} / \mathrm{s}$ allows for $10^{4} \mathrm{~m}^{3}$ of lava drain-back within 100 days, or about $0.1 \%$ of the mass of the extruded lava. Satellite SAR interferometric measurements indicated the volume of the lava stayed at about $1.5 \times 10^{7} \mathrm{~m}^{3}$ to within the measurement error (about $\left.0.1 \times 10^{7} \mathrm{~m}^{3}\right)($ Ozawa, 2011) for more than one year. Therefore, we infer that for the 2011 eruption of the Shinmoedake volcano, the degassing and crystallization of the andesitic lava greatly increased its viscosity (by more than five orders of magnitude), which prevented the lava from draining back.

Quantitative evaluation of lava viscosity in drain-back of other volcanoes is not available from litherature. In basaltic lava, initial temperature of magma is generally over $1050^{\circ} \mathrm{C}$, and only small supercooling is expected by degassing of water during magma ascent. In such case, increase of viscosity of lava is minimal and drain-back of lava may take place if magma chamber and conduit shrinks after the eruption. In the 2004 eruption of Asama volcano, some drain-back of the andesite lava occurred (Urabe et al., 2006). $\mathrm{SiO}_{2}$ content of the andesite is $58 \mathrm{wt} \%$ (Miyake et al., 2005) and the lava temperature is estimated to be 1000$1100^{\circ} \mathrm{C}$ by pyroxene thermometry (Tsugane et al., 2006). They showed crystal-size distribution for microlites in the groundmass, although the amount of microlites is not available, and it is difficult to estimate viscosity of the emplaced lava.

In the case of the 2011 eruption of Shinmoedake volcano, the error term in our estimate of the drain-back is an order of magnitude, due mainly to the estimation error of the viscosity. The upper estimate of the rate suggests that some observable drain-back of the lava could have occurred. GNSS measurements made by the Geographical Survey Institute of Japan showed inflation of the whole Kirishima volcano group after the 2011 eruption at a rate similar to that before the eruption (Nakao et al., 2011). This observation suggests infilling of the magma chamber at depth $10 \mathrm{~km}$ after the eruption. Such refilling of the chamber may compensate for decreased chamber and conduit overpressures after the eruption, and decrease potential for drain-back of extruded lava. The actual processes of the eruption and aftermath of the volcano need to be more precisely measured and analyzed. The present work showed that the andesitic magma that filled the crater of Shinmoedake experienced a large viscosity increase due to degassing and crystallization, which may have prohibited the extruded lava from draining back.

\section{Conclusions}

1. We analyzed lava blocks thrown by the Vulcanian explosion on 1 February 2011 from the lava-filled crater of the Shinmoedake volcano.

2. The bulk viscosity of the lava blocks was estimated to be $10^{9.8(+1.5-1.2)} \mathrm{Pa}$ s from the glass composition, glass water content, temperature, and crystal contents. The viscosity of the magma in the chamber is estimated to be $10^{3.8-4.1} \mathrm{~Pa}$ s, indicating that degassing and crystallization of the magma caused the viscosity to increase by more than five orders of magnitude.

3 We estimated the conduit radius from the eruption rate of the subplinian explosion that preceded the eruption to be 4.5-6 meters by using CONFLOW modeling and the eruption rate data of Kozono et al. (2013).

4 The drain-back rate of the lava that filled the crater was estimated to be $200-10^{5} \mathrm{~m}^{3} / 100$ days which corresponds to less than $1 \mathrm{vol} \% \%$ of the total amount of emplaced lava in the crater, suggesting that large increase of the andesitic lava's viscosity may have prevented it from draining back.

Acknowledgments. The Vulcanian blocks were kindly donated by Prof. Hiroshi Shimizu and Dr. Takeshi Matsushima of SEVO, Kyushu University. The XRF analyses were made possible through the kind support of Prof. Terakado of Kobe University and Dr. Satish-Kumar of Shizuoka University (now at Niigata University). Support in the EPMA analyses is given by Dr. Yusuke Seto. Dr. Tomofumi Kozono generously informed us about their conduit modeling. The paper has been greatly improved by incorporation of the comments of two anonymous reviewers and Prof. McNutt. This study was supported by funds of Center for Integrated Research and Education of Natural Disaster, Shizuoka University and Japan Society for Promotion of Science to H.S.

\section{References}

Anderson, D. J., D. H. Lindsley, and P. M. Davidson, QUILF: A pascal program to assess equilibria among $\mathrm{Fe}-\mathrm{Mg}-\mathrm{Mn}$ - Ti oxides, pyroxenes, olivine and quartz, Comput. Geosci., 19, 1333-1350, 1993.

Barker, S., D. R. Sherrod, M. Lisowski, C. Heliker, and J. S. Nakata, Correlation between lava-pond drain-back, seismicity, and ground deformation at Pu'u O'o, US Geol. Surv. Prof. Pap., 1676, 53-62, 1998.

Blundy, J. D., K. V. Cashman, and M. Humphreys, Magma heating by decompression-driven crystallization beneath andesite volcanoes, $\mathrm{Na}$ ture, 443, 76-80, doi:10.1038/nature05100, 2006.

Chadwick, W. W., Quantitative constraints on the growth of submarine lava pillars from a monitoring instrument that was caught in a lava flow, $J$. Geophys. Res., 108(B11), 2534, doi:10.1029/2003JB002422, 2003.

Costa, A., L. Caricchi, and N. Bagdassarov, A model for the rheology of particle-bearing suspensions and partially molten rocks, Geochem. Geophys. Geosyst., 10, Q03010, doi:10.1029/2008GC02138, 2009.

Fox, C. G., W. W. Chadwick, and R. W. Embley, Direct observation of a submarine volcanic eruption from a sea-floor instrument caught in lava flow, Nature, 412, 727-729, 2001.

Fukuyama, H., Heat of fusion of basaltic magma, Earth Planet. Sci. Lett., 73, 407-414, 1985.

Ghiorso, M. S. and B. W. Evans, Thermodynamics of rhombohedral oxide solid solutions and a revision of the Fe-Ti two oxide geothermometer and oxygen-barometer, Am. J. Sci., 308, 957-1039, 2008.

Giordano, D., J. K. Russell, and D. B. Dingwell, Viscosity of magmatic liquids: A model, Earth Planet. Sci. Lett., 271, 123-134, 2008.

Ida, Y., K. Yamaoka, and H. Watanabe, Model of volcanic activity associated with magma drain-back: Implication for eruption of Izu-Oshima volcano after December 1986, Bull. Earthq. Res. Inst., 63, 183-200, 1988 (in Japanese with English abstract).

Imura, R., Geology of Kirishima volcano, Bull. Earthq. Res. Inst., Univ. Tokyo, 9, 189-209, 1994 (in Japanese with English abstract).

Imura, R. and T. Kobayashi, Eruptions of Shinmoedake volcano, Kirishima Volcano Group, in the last 300 years, Bull. Volcanol. Soc. Jpn., 36, 135 148, 1991 (in Japanese with English abstract).

Ishibashi, H. and H. Sato, Viscosity measurements of subliquidus magmas: Alkali olivine basalt from the Higashi-Matsuura district, southwest 
Japan, J. Volcanol. Geotherm. Res., 160, 223-238, 2007.

Jaupart, C. and S. Tait, Dynamics of eruptive phenomena, Rev. Mineral., 24, 213-238, 1991.

Johannes, W. and F. Holtz, Petrogenesis and Experimental Petrology of Granitic Rocks, 335 p., Springer Verlag, Berlin, 1996.

Kazahaya, K., H. Shinohara, and G. Saito, Excessive degassing of IzuOshima volcano: Magma convection in a conduit, Bull. Vocanol., 56, 207-216, 1994.

Kozono, T., H. Ueda, T. Ozawa, T. Koyaguchi, E. Fujita, A. Tomiya, and Y. J. Suzuki, Magma discharge variations during the 2011 erution of Shinmoe-dake volcano, Japan, revealed by geodetic and satellite observations, Bull. Volcanol., 75, doi:10.1007/s00445-013-0695-4, 2013.

Krieger, I. M. and T. J. Dougherty, A mechanism for non-Newtonian flow in suspensions of rigid spheres, Trans. Soc. Reol., 3, 137-152, 1959.

Marsh, B. D., On the crystallinity, probability of occurrence, and rheology of lava and magma, Contrib. Mineral. Petrol., 78, 85-98, 1981.

Mastin, L. G., Insights into volcanic conduit flow from an opensource numerical model, Geochem. Geophys. Geosyst., 3, doi:10.1029/2001GC000192, 2002.

Mastin, L. G. and M. S. Ghiorso, Adiabatic temperature changes of magma-gas mixtures during ascent and eruption, Contrib. Mineral. Petrol., 141, 307-321, 2001.

Minakami, T., T. Ishikawa, and K. Yagi, The 1944 eruption of volcano Usu in Hokkaido, Japan, Bull. Volcanol., 11, 45-157, 1951.

Miyake, Y., K. Takahashi, T. Tsugane, K. Makino, H. Kakuzen, K. Nishiki, T. Fukui, and Shinshu Univ. Res. Group for Asama 04 eruptions, On the essential ejecta of the September 2004 eruptions of the Asama volcano, central Japan, Bull. Volcan. Soc. Jpn., 50, 333-346, 2005 (in Japanese with English abstract).

Moore, G., T. Vennemann, and I. S. E. Carmichael, An empirical model for the solubility of $\mathrm{H}_{2} \mathrm{O}$ in magmas to 3 kilobars, Am. Mineral., 83, 36-42, 1998.

Mueller, S., E. W. Llewellin, and H. M. Mader, The effect of particle shape on suspension viscosity and implications for magmatic flows, Geophys. Res. Lett., 38, doi:10.1029/2011GL047167, 2011.

Nakada, S., H. Shimizu, and T. Ohta, Overview of the 1990-1995 eruption of Unzen volcano, J. Volcanol. Geotherm. Res., 89, 1-22, 1999.

Nakao, S., Y. Morita, K. Goto, H. Yakiwara, S. Hirano, H. Ueda, T. Kozono, and J. Oikawa, Crustal deformation of Kirishima volcano before eruptions in January 2011, Abstract in Japan Geoscience Union, 2011
General Meeting, SVC050-10, 2011.

Oba, Y., Y. Katsui, H. Kurasawa, Y. Ikeda, and T. Uda, Petrology of historic rhyolite and dacite from Usu volcano, north Japan, J. Fac. Sci., Hokkaido Univ., Ser. 4, 20, 275-290, 1983.

Ozawa, T., Change detection around the crater by spaceborne SAR, in Report of Emergency Research and Studies for the 2011 Eruption of the Kirishima Volcano (Shinmoe-dake), 1-6, 50-57, 2011 (in Japanese).

Putirka, K. D., Thermometers and barometers for volcanic systems, Rev. Mineral. Geochem., 69, 61-111, 2008.

Suzuki, Y., A. Yasuda, N. Hokanishi, T. Kaneko, S. Nakada, and T. Fujii, Syneruptive deep magma transfer and shallow magma remobilization during the 2011 eruption of Shinmoe-dake, Japan-Constraints from melt inclusions and phase equilibria experiments, J. Volcanol. Geotherm. Res., 257, 184-204, 2013.

Swanson, D. A., Magma supply rate at Kilauea volcano, 1952-1971, Science, 175, 169-170, 1972.

Swanson, D. A. and R. T. Holcomb, Regularities in growth of the Mount St. Helens dacite dome, 1980-1986, in Lava Flows and Domes, edited by J. H. Fink, pp. 3-24, Springer Verlag, New York, 1990.

Tsugane, T., K. Makino, Y. Miyake, and K. Takahashi, Crystal size distribution and crystallization process of the ejecta from the September 2004 eruptions of the Asama Volcano, Central Japan, Bull. Volcanol. Soc. Jpn., 51, 49-61, 2006 (in Japanese with English abstract).

Urabe, B., N. Watanabe, and M. Murakami, Topographic change of the summit crater of Asama volcano during the 2004 eruption derived from airborne synthetic aperture rader (SAR) measurements, Bull. Geogr. Surv. Inst., 53, 1-6, 2006.

Wallace, P. J. and A. T. Anderson, Effects of eruption and lava drainback on the $\mathrm{H}_{2} \mathrm{O}$ contents of basaltic magmas at Kilauea volcano, Bull. Volcanol., 59, 327-344, 1998.

Watanabe, H., S. Okubo, and S. Sakashita, Drain-back process of basaltic magma in the summit conduit detected by microgravity observation at Izu-Oshima volcano, Japan, Geophys. Res. Lett., 25, 2865-2868, 1999.

Westrich, H. R., Determination of water in volcanic glasses by KarlFischer titration, Chem. Geol., 63, 335-340, 1987.

H. Sato (e-mail: hsato47@gmail.com), K. Suzuki-Kamata, E. Sato, K. Sano, K. Wada, and R. Imura 